\title{
Johann Reinhold i Georg Forsterowie - osiemnastowieczni badacze natury i podróżnicy
}

\section{Wstęp}

W 1816 r. kasztelanowa Konstancja Biernacka z Sieradza postanowiła odwiedzić Gdańsk ${ }^{1}$. Była wizytatorką żeńskich szkół i na potrzeby uczących się tam panien redagowała pedagogiczne pisma. Podczas zwiedzania tarego miasta zainteresowały ją znajdujące się w Zielonej Bramie eksponaty Towarzystwa Przyrodników². Wśród nich wyróżniały się egzotyczne artefakty: „[...] wszystko dzieła mieszkańców Morza Spokojnego, mianowicie Otajczyków, które to osobliwości są darem gdańszczanina, co z Cookiem świat opłynął, a w pamiątkę podróży zbiór swój Ojczyźnie poświęcił"3.

Darczyńcą był urodzony w Mokrym Dworze pod Gdańskiem Georg Forster, który owe eksponaty przywiózł z podróży odbytej pod dowództwem legendarnego kapitana Jamesa Cooka ${ }^{4}$ Ta egzotyczna wyprawa była jednym z wielu przedsięwzięć naukowych i podróżniczych, które wypełniły życie George’a Forstera i jego ojca Johanna Reinholda. Towarzysząca im sława podróżników, badaczy i autorów poczytnych publikacji, w latach osiemdziesiątych XVIII w., w czasach reformy

1 Konstancja z Małachowskich Biernacka (1773-1842), cytaty z jej książki: Podróż z Włodawy do Gdańska powrotem do Nieborowa w roku 1816 opisana w listach Wandy, Eweliny i Leokadii przez Polkę K, z H. Ma. Bcka (Wrocław: Wilhelm Bogumił Korn, 1823).

2 Naturforschende Gesellschaft, jego zbiory stały się podwaliną późniejszego Muzeum Przyrodniczego. Zbiór przedmiotów zgromadzonych przez Forsterów jest prezentowany jako osobna kolekcja w muzeum Sammlung für Völkerkunde w Getyndze.

3 Konstancja z Małachowskich Biernacka, Podróż z Włodawy, 144-145.

4 James Cook (1728-1779), żeglarz angielski, przeprowadził trzy wielkie wyprawy: na „Endeavour” (1768-1771), na „Resolution”/„Adventure” (1772-1775) i na „Resolution”/„Discovery” (1776-1779). Norman Davies, Na krańce świata. Podróż historyka przez historię (Kraków: Społeczny Instytut Wydawniczy „Znak” 2017), 539-545. 
polskiego systemu oświaty, zachęciła członków Komisji Edukacji Narodowej do zaproponowania George'owi Fosterowi stanowiska profesora w Wilnie.

Tekst o Forsterach powstał na podstawie nielicznych tłumaczeń na język polski dzieł George'a Forstera ${ }^{5}$, rozproszonej literatury przedmiotu ${ }^{6}, w$ tym także niemiec$\mathrm{kiej}^{7}$. Cennym, bodaj najszerszym omówieniem działalności Forsterów w języku polskim, z którego korzystałem, jest nieopublikowana praca doktorska Joanny Bramley, Johann Reinhold Forster i Johann George Adam Forster - XVIII-wieczni pomorscy badacze Wysp Poludniowego Pacyfiku, napisana w 2004 r., pod kierunkiem prof. dr hab. Andrzeja Grotha ${ }^{8}$. Autorka wnikliwie zapoznała się z naukową działalnością Forsterów podczas ich pobytu w Wielkiej Brytanii, wykorzystując w tym wątku niezwykle ciekawe i nigdy wcześniej nieprezentowane w takiej obfitości w języku polskim źródła angielskie ${ }^{9}$.

5 „Mowa Jerzego Forstera pt. Limites Historiae naturalis wygłoszona 2 lutego 1785 r. w Szkole Głównej Wielkiego Księstwa Litewskiego w Wilnie”, Memorabilia Zoologica 7 (1961); Jerzy Forster, Podróż naokoło świata, wybrał i przełożył Michał Ronikier (Warszawa: Czytelnik, 1977); Jan Jerzy Forster, „Dziennik podróży po Polsce”, przełożył z języka niemieckiego, wstępem i przypisami opatrzył Wacław Zawadzki, Archiwum Historii Medycyny 21 (1958); Jerzy Forster, „Podróż po Polsce”, w Polska Stanisławowska w oczach cudzoziemców, red. Zawadzki, t. 1 (Warszawa: Państwowy Instytut Wydawniczy, 1963); wybór listów zawartych w osobnym rozdziale Józef M. Ziółkowski, Małgorzata Olczak, Z Forsterami i Cookiem na koniec świata (Pelplin: Bernardinum, 2011).

${ }^{6}$ Szczególnie cenne są ustalenia dotyczące działalności G.A. Forstera w Wilnie, m.in. Stanisław Domoradzki, Zofia Pawlikowska-Brożek, „Uniwersytet Wileński”, Roczniki Polskiego Towarzystwa Matematycznego, Seria 2, Wiadomości Matematyczne XXXV (1999); Zygmunt Fedorowicz, „Ewolucjonizm na Uniwersytecie Wileńskim przed Darwinem", Memorabilia Zoologica 4 (1960); Fedorowicz, „Katedra Historii Naturalnej w dawnej Wszechnicy Wileńskiej”, Studia i Materiały z Dziejów Nauki Polskiej, Historia Nauk Biologicznych i Medycznych 5(1) (1957); Fedorowicz, „Organizacja studiów przyrodniczych na Wszechnicy Wileńskiej w latach 1781-1832”, Studia i Materiały z Dziejów Nauki Polskiej, Historia Nauk Biologicznych i Medycznych 5(1) (1957); Karol Sauerland, „Georg Forster w Wilnie", Przeglad Filozoficzno-Literacki 27 (2010) i inne.

7 Georg Forster, „Brief aus Paris an seine Frau”, w Geschichte in Quellen (München: Bayerischer Schulbuch-Verlag, 1981); Georg Forster, „Die Kunst und das Zeitalter”, w Georg Forster, Werke. Sämtliche Schriften, Tagebücher, Briefe (Berlin: Briefe Akademie-Verlag, 1958); Georg Forster, „Über Proselytenmacherei”, w Georg Forster, Werke. Sämtliche Schriften, Tagebücher, Briefe (Berlin: Briefe Akademie-Verlag, 1958); Georg Forster, Werke (Frankfurt am Main: Insel Verlag, 1970), a także cytatów zawartych w Johannes Paul, „Georg Forster: Empfindsame Weltumseglung”, w Abenteuerliche Lebensreise - Sieben biographische Essays (Minden: Wilhelm Köhler Verlag, 1954).

8 Egzemplarz pracy w zbiorach Biblioteki Uniwersytetu Gdańskiego, III 38232/PD.

9 Próbę ujęcia życiorysów obu Forsterów, choć w stopniu mniej zaawansowanym i popularyzującym działalność obu naukowców i badaczy podjęli: Jerzy Kornacki, „Jerzy Adam Forster - naukowiec rodem z Żuław Gdańskich”, Teki kociewskie 9 (2015); Ziółkowski, Olczak, $Z$ Forsterami i Cookiem oraz Kazimiera Augustowska, „Jerzy Forster, uczony i podróżnik epoki oświecenia. Karta z dziejów nauki gdańskiej”, Zeszyty Naukowe Wydziału Biologii i Nauk o Ziemi Uniwersytetu Gdańskiego 5 (1975). 


\section{Imigranci ze Szkocji}

Rodzina Forsterów pochodziła ze Szkocji ${ }^{10}$. Po wybuchu w 1642 r. wojny domowej jej protoplaści opuścili ojczyznę, przenosząc się na teren Prus Królewskich ${ }^{11}$. Georg Forster prawdopodobnie jako pierwszy osiedlił się w Nowem nad Wisłą. Jego syn, Adam Simon Forster, w 1667 r. osiadł w Tczewie i od 1670 r. piastował godność burmistrza tego miasta ${ }^{12}$. Potomkowie Adama utrzymali miejsca w gronie tczewskich notabli, stając się niejako dziedzicznymi burmistrzami tego miasta - Georg ${ }^{13}$ od 1702 r. $^{14}$, Georg Reinhold od 1733 r. Ten ostatni, ożeniony z wdową Ewą Plath z domu Wolf ${ }^{15}$, był ojcem Johanna Reinholda, który urodził się w Tczewie 22 października 1729 r. ${ }^{16}$

Johann Reinhold wyrastał w otoczeniu ludzi o ciekawym życiorysie ${ }^{17}$, wykształconych i posługujących się kilkoma językami. Sam był wybitnie uzdolniony, interesował się naukami przyrodniczymi, a zwłaszcza medycyną ${ }^{18}, \mathrm{z}$ dużą łatwością uczył się języków klasycznych i nowożytnych, i wiadomo, że łącznie władał ich siedemnastoma ${ }^{19}$. Mimo tak wyraźnie ukierunkowanych zainteresowań, po ukończeniu elitarnego Gimnazjum w Berlinie ${ }^{20}$ wybrał się na gwarantujące stabilne dochody studia teologiczno-filozoficzne na Uniwersytecie w Halle ${ }^{21}$. Wrócił do domu w 1753 r. na wieść o śmierci ojca, sprzedał kamienicę przy rynku w Tczewie i przeniósł się

10 I uważali się za Szkotów. Wynika to z wielu odniesień, jakie są zawarte w listach George’a Forstera. „Rozmowa Józefa Ziółkowskiego z Magdaleną Grzyb - autorką tłumaczeń listów Jerzego Adama Forstera", w Ziółkowski, Olczak, Z Forsterami i Cookiem, 68.

11 Kornacki, „Jerzy Adam Forster - naukowiec rodem z Żuław”, 125.

12 Ibidem, 126.

13 (1663-1726).

14 Piastował ten urząd przez kolejne dwadzieścia cztery lata, do śmierci. Ibidem.

15 (1692-1748). Nazwisko Wolf pisane niekiedy Wolff.

16 Ibidem, 127. Johann Reinhold był jedynym dzieckiem tej pary. Miasto Tczew uhonorowało badacza i podróżnika pod koniec XIX w., nadając jego imię jednej z ulic. Na kamienicy, w której się urodził, umieszczono tablicę upamiętniającą to wydarzenie. W 1914 obie te pamiątki zniknęły z planów miasta. Roman Landowski, Nowy bedeker kociewski (Gdańsk: Oscar, 2002). Dom urodzin J.R. Forstera (obecnie pl. Hallera 4) ponownie oznaczono tablicą pamiątkową w 2005 dzięki staraniom Ireneusza Dunajskiego. Ziółkowski, Olczak, Z Forsterami i Cookiem, 10-11.

17 M.in. Godfryd Wolf, kapitan w regimencie gwardii koronnej i marszałek dworu księcia Stanisława Poniatowskiego, ojca króla Stanisława Augusta. Z tej samej rodziny wywodził się znany astronom gdański, Nataniel Mateusz Wolf.

18 Johann Reinhold zamierzał nawet studiować medycynę. Jego ojciec nie wykazał zrozumienia dla tych planów. Liczył, że syn wybierze prawo. Joanna Bramley, Johann Reinhold Forster i Johann George Adam Forster - XVIII-wieczni pomorscy badacze Wysp Południowego Pacyfiku, praca doktorska napisana pod kierunkiem prof. dr hab. Andrzeja Grotha, Gdańsk 2004, 26.

19 Ibidem. W tym języka koptyjskiego.

20 Gimnazjum Joachimowskie w Berlinie. Ukończył je w 1748. Wcześniej uczył się w Tczewie i gimnazjum w Kwidzynie. Ibidem, 24.

${ }^{21}$ Akademia Fridericiana cieszyła się w tym czasie sporą popularnością wśród gdańszczan. Historia Gdańska 3(1), red. Edmund Cieślak (Gdańsk: Instytut Historii Polskiej Akademii Nauk i Zakład Historii Gdańska i Dziejów Morskich Polski, 1993), 678. 
do odległego o jedną milę od Gdańska Mokrego Dworu²2, gdzie objął posadę pastora ewangelickiego ${ }^{23}$. Ożenił się i doczekał siedmiorga dzieci ${ }^{24}$. Tam też urodził się, 26 listopada $1754 \mathrm{r}^{25}$, jego najstarszy syn, zapisany w księgach parafialnych jako Johann Georg Adam, ale przez wszystkich nazywany George'em.

Georg, podobnie jak reszta młodszego rodzeństwa, nie uczęszczał do szkoły, a ich nauczycielem był ojciec. Swoje lekcje prowadził w salonie na plebani, a także $\mathrm{w}$ terenie - w ogrodzie i na żuławskich polach, podczas licznych wycieczek. Ojciec stosował metodę wprowadzania podopiecznych $\mathrm{w}$ świat nauki poprzez uczestnictwo w interesujących jego samego przedsięwzięciach. Dzieciom podobał się ten sposób nauczania. Razem zbierali okazy do zielników. Terenowe zajęcia miały również walor dodatkowy - zmuszając dzieci do wysiłku fizycznego, między innymi podczas szybkich marszów - rodzic wpływał na ich kondycję i odporność. Utalentowany Georg po ojcu odziedziczył zdolności lingwistyczne ${ }^{26} \mathrm{i}$ wkrótce stał się najbliższym pomocnikiem ojca w edukacji młodszych dzieci.

Johann Reinhold był pedagogiem entuzjastą, szczerze zaangażowanym w kształcenie swoich pociech. W posiadaniu pastora znajdywała się, jak na owe czasy zaskakująco pokaźna, biblioteka. Jednak liczba dzieł teologicznych była dosyć skromna. Nie brakowało za to pozycji z dziedziny historii, językoznawstwa i przede wszystkim nauk przyrodniczych ${ }^{27}$. Gdy zauważył, że zakupione podczas studiów podręczniki do klasyfikacji okazów naturalnych są przestarzałe i niewystarczające, wybrał się pieszo do Gdańska i zakupił nowe: Linneusza Systema Naturae i Philosophia Botanica oraz Definitiones Generum Plantarum Christiana Gottlieba Ludwiga. Atlasy pomagały dzieciom nazwać dostrzeżone w okolicy rośliny i zwierzęta. George’owi powierzył ojciec ustalenie ich powiązań w świecie natury, wedle nowych wzorców systematyki, jaką zaproponował szwedzki badacz, Linneusz. W ten sposób przysposabiał go do przyszłej pracy naukowej. Edukacja obejmowała również arytmetykę, francuski i łacinę. Pastor celowo łączył dyscypliny, ucząc dwóch rzeczy jednocześnie, w przypadku np. religii nie

22 Nassenhuben, obecnie Wiślina.

23 Gerhard Steiner, „Forster Reinhold w Neue Deutsche Biographie”, t. 5 (Berlin: Duncker \& Humblot, 1961), 301. Jednocześnie był związany z kalwińskim kościołem pw. Apostołów Piotra i Pawła w Gdańsku, gdzie wygłaszał kazania. Do jego parafian należeli przedstawiciele wpływowych rodzin mieszczańskich: Schwarzwald, Uphagen, Conradi, Schwerin. Kornacki, „Jerzy Adam Forster - naukowiec rodem z Żuław”, 130.

24 Jego wybranką była Justyna Elżbieta Nicolei. Ibidem.

25 Steiner, „Forster Georg”, w Neue Deutsche Biographie, t. 5 (Berlin: Duncker \& Humblot, 1961), 301.

${ }^{26}$ Jego biograf, Heinrich König, napisał: „W dzieciństwie od ojca nauczył się łaciny, od matki i ciotki polskiego. Jako chłopiec nauczył się niemieckiego”. Cytuje go Fedorowicz, „Ewolucjonizm na Uniwersytecie Wileńskim przed Darwinem", 10. Tymczasem podczas pobytu w Wiedniu, w 1784, i rozmowy z cesarzem Georg stwierdził jednoznacznie, że języka polskiego nie zna. Ziółkowski, Olczak, Z Forsterami i Cookiem, 62.

${ }^{27}$ Paul, „Georg Forster: Empfindsame Weltumseglung”, 67-112. 
skupiał się tylko i wyłącznie na zasadach wiary, dopełniał je zawsze komentarzem, dotyczącym dziejów Żydów, historii chrześcijaństwa, a nawet prawa ${ }^{28}$. Syn przejął tę umiejętność i w przyszłości podczas prowadzonych wykładów zwracał uwagę na liczne powiązania między dyscyplinami naukowymi i ich wewnętrzne transformacje: „Mineralogię wchłonęła chemia. Botanika, która ledwo dopiero przybrała postać nauki, dostała się pod władzę lekarzy. Wreszcie zoologia, której pożyteczność jest jasna jak słońce, ze względu na pokrewieństwo człowieka z resztą zwierząt, nie zdołała znaleźć miejsca, gdzie by się zadomowiła" ${ }^{29}$.

Szara codzienność duszpasterskiej posługi na prowincji, skromna pensja, ledwo wystarczająca na utrzymanie powiększającej się z roku na rok rodziny sprawiły, że Johann Reinhold szukał możliwości zmiany. Gdy ta pojawiła się na horyzoncie, zareagował pozytywnie.

\section{Nad Wołgą i Tamizą}

Kiedy w 1765 r. Hans Wilhelm von Rehbinder, rosyjski rezydent w Gdańsku, zaproponował Johannowi Reinholdowi przejście na służbę carską i wyjazd do Rosji, pastor przyjął tę propozycję. W podróż zabrał, w charakterze pomocnika, jedenastoletniego syna ${ }^{30}$. Chłopiec był jak na swój wiek podobno wyjątkowo dojrzały. Forsterowie udali się do Petersburga, tam po raz pierwszy i jedyny Georg przez kilka miesięcy uczęszczał do szkoły ${ }^{31}$.

Caryca Katarzyna formalnie powołała Johanna Reinholda w skład ekspedycji, która miała zbadać warunki funkcjonowania oraz ewentualnego rozwoju niemieckich osiedli nad Wołgą ${ }^{32}$. Po odebraniu instrukcji wyprawa ruszyła w kierunku Saratowa. Jednak po zakończeniu trwającej rok misji, w trakcie przygotowywania dokumentacji, doszło do konfliktu między byłym pastorem a jego zleceniodawcami. Raport Reinholda nie spodobał się władzom, jako że wskazywał na nieprawidłowości w funkcjonowaniu administracji carskiej. Gdańszczanie nie otrzymali więc pełnej zapłaty ${ }^{33}$ i znaleźli się w trudnej sytuacji, musieli opuścić Rosję, podczas gdy plebania w Mokrym Dworze była już zajęta ${ }^{34}$.

28 Bramley, Johann Reinhold Forster i Johann George Adam Forster, 35.

29 „Mowa Jerzego Forstera pt. Limites Historiae naturalis wygłoszona 2 lutego 1785 r. w Szkole Głównej Wielkiego Księstwa Litewskiego w Wilnie”, 44.

30 Steiner, „Forster Georg”, 301.

31 Joanna Bramley, „Georg Forster w Szkole Głównej Wielkiego Księstwa Litewskiego”, Teki Gdańskie 5 (2002): 20.

32 Paul, „Georg Forster: Empfindsame Weltumseglung”.

33 Decyzją Katarzyny wstrzymano wypłatę dalszej części oraz odsunięto Johanna Reinholda od komisji naukowych i rządowych. Kornacki, „Jerzy Adam Forster - naukowiec rodem z Żuław”, 131.

${ }^{34}$ Wyjeżdżając do Rosji, Johann Reinhold wziął roczny urlop i zwolnił posadę. 
Aby uratować rodzinę przed zubożeniem, sprzedano rodzinną cenną bibliotekę $^{35}$. To nie polepszyło sytuacji na długo i Forsterowie wkrótce podjęli odważną decyzję. Latem 1766 r., Johann Reinhold wraz z synem George’em udali się do Anglii, a dwa lata później dołączyła do nich reszta rodziny ${ }^{36}$.

Początek pobytu w Anglii był niezbyt udany, z konieczności sprzedawali okazy przywiezione z podróży po Rosji ${ }^{37}$. Dopiero po niecałym roku Johann Reinhold otrzymał posadę profesora na jednej z najbardziej postępowych wyższych europejskich uczelni, w Warrington ${ }^{38}$, w Lancashire. Uczelnia, przeżywająca swój rozkwit w latach 1762-1780, w programie studiów starała się uwzględniać zainteresowania naukowe swoich czasów, wprowadzała do niego nowe dyscypliny i rezygnowała ze sztywnego rozdzielenia studentów od profesorów. Porządek ten, niekiedy krytykowany przez konserwatystów, sprawdzał się w praktyce. Absolwenci Warrington cieszyli się uznaniem i nie narzekali na brak zajęcia ${ }^{39}$. Podejmowali się zadań związanych z prowadzeniem własnych interesów, działali w polityce i na polu naukowym.

W Warrington poza uczelnią funkcjonowało prestiżowe wydawnictwo ${ }^{40}$, naukowa i dobrze wyposażona biblioteka ${ }^{41}$, ogród botaniczny oraz gabinet $\mathrm{z}$ okazami flory i fauny ${ }^{42}$. Johann Reinhold został zatrudniony na uczelni 30 czerwca 1767 r. jako wykładowca języków nowożytnych ${ }^{43}$ i historii naturalnej. W pracy dydaktycznej wykazał się zaangażowaniem i innowacyjnością. Uznając, że dostępne podręczniki do mineralogii są nieodpowiednie, stworzył własny, oparty na ustaleniach i metodach Linneusza ${ }^{44}$. Uczelniana pensja dawała szansę na uzyskanie stabilizacji. Dzięki temu jego syn Georg, który praktykował u kupca w Londynie, zajmując się jednocześnie tłumaczeniem tekstów (już jako dwunastolatek przetłumaczył Historię Rosji Michaiła Łomonosowa, którą wydano jako A chronological abridgment of the Russian history; translated from the original Russian ... $\left.{ }^{45}\right)$ i udzielaniem korepetycji, mógł na pewien czas zagościć w Warrington. Także jego młodszy brat Carl rozpoczął tam studia ${ }^{46}$.

Niestety, wkrótce Johann Reinhold poróżnił się wykładowcami w Warrington i w 1770 r. musiał ustąpić z posady. Rodzina przeniosła się do Londynu, gdzie oddał się naukowej pracy, publikując artykuły o Rosji, m.in. w „Philosophical Transactions”,

35 Paul, „Georg Forster: Empfindsame Weltumseglung”.

36 Steiner, „Forster Georg”, 301.

37 Bramley, Johann Reinhold Forster i Johann George Adam Forster, 46.

38 Steiner, „Forster Reinhold”, 301. Funkcjonowała od 1757.

39 Bramley, Johann Reinhold Forster i Johann George Adam Forster, 52.

40 Wydawnictwo Williama Eyresa.

${ }^{41}$ Warrington Circulating Library.

42 Orford Hall.

43 W latach 1767-1768 uczył języka francuskiego i niemieckiego.

44 Itroduction to Mineralogy, London 1768.

45 Kornacki, „Jerzy Adam Forster - naukowiec rodem z Żuław”, 132.

46 Bramley, Johann Reinhold Forster i Johann George Adam Forster, 56. 
a dwa lata później został członkiem The Royal Society. Nie poprawiło to jednak ogólnie złej sytuacji finansowej; w 1770 r. rodzina Forsterów zalegała z czynszem i musiała kupować na kredyt. Trudny czas trwał do 1772 r., kiedy to Johannowi Reinholdowi zaproponowano udział w wyprawie na wyspy południowego Pacyfiku. Miał ją poprowadzić słynny ze swoich żeglarskich dokonań kapitan James Cook. Oznaczało to szansę na odmianę losu.

\section{Zamustrowani}

Jednym z celów wyprawy było kontynuowanie poszukiwań Terra Australis ${ }^{47}$ wielkiego południowego kontynentu ${ }^{48}$. Pośpiesznie przygotowywano odpowiednie statki, uzupełniano składy osobowe, w tym grupy badawczej, jako że w ostatnim momencie zrezygnowali z uczestnictwa w wyprawie angielski botanik Joseph Banks ${ }^{49}$ i szwedzki przyrodnik Daniel Solander ${ }^{50}$. Po konsultacjach z członkami The Royal Society, zaproponowano Johannowi Reinholdowi udział w rejsie. Forster przyjął propozycję wraz z pensją 4000 funtó $\mathrm{w}^{51}$; władze wyraziły także zgodę na udział w wyprawie jego osiemnastoletniego już wówczas syna - George’a ${ }^{52}$.

Do udziału w wyprawie przygotowywano dwa żaglowce: „Resolution”, prowadzony przez kapitana Cooka i „Adventure”, znajdujący się pod komendą kapitana Tobiasza Furneauxa ${ }^{53}$. Wczesnym rankiem 13 lipca 1772 r. okręty wypłynęły z portu Plymouth w pierwszy, okołoziemski rejs prowadzony ku wschodowi ${ }^{54}$.

Po latach, Georg Forster napisał: „11 września 1772 r. zostaliśmy wraz z ojcem wyznaczeni do wzięcia udziału w tej wyprawie celem zebrania, opisania i oddania na rysunkach okazów przyrody, z którymi możemy się zetknąć w czasie naszej wędrówki” ${ }^{55}$.

W ten sposób dla obu Forsterów zaczynała się największa przygoda ich życia. Na podstawie dziennika pokładowego, wspomnień uczestników rejsu, można dokładnie odtworzyć trasę żeglugi. Po wizycie na Maderze ${ }^{56}$ znaleźli się jesienią 1772 r. ${ }^{57}$ na Przylądku Dobrej Nadziei, gdzie spotkali doktora Andersa Sparrmana,

47 Davies, Na krańce świata, 541.

48 Ibidem.

49 Joseph Banks (1743-1820), brytyjski naturalista, prezes Royal Society w latach 1778-1820.

50 Daniel Solander (1733-1782), szwedzki przyrodnik, uczeń Karla Linneusza.

51 Bramley, „Georg Forster w Szkole Głównej Wielkiego Księstwa Litewskiego”, 21.

52 Lata młodości były szczególnie dla George’a Forstera łaskawe. Napisał o nich: „Piękna jest młodość, kiedy uszczęśliwia nas doznanie”. Forster, „Die Kunst und das Zeitalter”, 14.

53 Tobias Furneaux (1735-1781), angielski żeglarz. Forster, Podróż naokoło świata, 15-16.

54 Ibidem, 18.

55 Ibidem, 15-16.

56 Ibidem, 21-36.

57 X-XI 1772. 
powracającego z podróży do Chin ${ }^{58}$. Sparrman, „biegły w medycynie, obdarzony wielką dobrocią serca i naturą filozofa”, chętnie został przyjęty na pokład „Resolution". Jego pomysłowość i wiedza wybawiły członków załogi z niejednej opresji ${ }^{59}$.

Podczas swojej wyprawy James Cook dotarł w rejony, gdzie dotąd nie pojawił się żaden Europejczyk. Żeglarze wytrwale poszukiwali nowego kontynentu. Usiłowali tego dokonać kilkukrotnie, podejmując próby przedarcia się jak najdalej w kierunku bieguna południowego od każdej z możliwych stron, w sezonie 1772-1773 na Oceanie Indyjskim, w sezonie 1774-1775 na Pacyfiku, w sezonie 1774-1775 na Atlantyku ${ }^{60}$. Za każdym razem na przeszkodzie stawała pokrywa lodowa. Mimo to „Resolution” przekroczył południowe koło polarne i dopłynął do 71 stopnia szerokości geograficznej południowej. W tym momencie od Antarktydy oddzielał go jeden dzień żeglugi i około $75 \mathrm{mil}^{61}$.

Tam właśnie, w strefie podbiegunowej, Johann Reinhold przeżył przygodę, która o mały włos nie zakończyła się dla niego tragicznie. Pewnego dnia, korzystając $\mathrm{z}$ faktu, że morze było spokojne, odpłynął wraz z astronomem Williamem Walesem ${ }^{62}$ na szalupie, aby sprawdzić kierunek prądów morskich oraz zbadać temperaturę morza na różnych głębokościach ${ }^{63}$. Niespodziewanie łódź podróżników otoczyła gęsta mgła i stracili kontakt z otoczeniem. Trzęsąc się z zimna, dryfowali zrozpaczeni pośród lodowego oceanu, nie mając odwagi ruszyć się z miejsca. Bezradnie czekali na ratunek i dopiero gdy dotarł do nich odległy dźwięk dzwonu okrętowego, zaczęli wiosłować. Cudem uniknęli „powolnej śmierci spowodowanej ostrością klimatu i brakiem pożywienia”. Georg opatrzył przygodę ojca pouczającym komentarzem: „Podróżnik narażony jest na morzu na rozliczne niebezpieczeństwa, często zaś zagrażają mu one wtedy, gdy najmniej się tego spodziewa" ${ }^{4}$.

Dnia 2 lutego 1773 r. złe warunki atmosferyczne doprowadziły do rozdzielenia obu okrętów. „Adventure” i „Resolution” straciły bezpowrotnie ze sobą kontakt, kontynuując wyprawę oddzielnie. Po ataku Maorysów na Nowej Zelandii i śmierci wielu członków załogi, dowodzący „Adventure” kapitan Furneux zdecydował się na powrót do domu. Do Anglii przybył 14 lipca $1774 \mathrm{r}^{65}$

Wycofujący się przed lodami „Resolution”, 26 marca 1773 r., po 123 dniach na morzu, dotarł do Nowej Zelandiii ${ }^{66}$, gdzie załoga okrętu przez sześć tygodni

58 Doktor Anders Sparrman (1748-1820), szwedzki przyrodnik i podróżnik, uczeń Carla Linneusza. Wyprawa do Chin Sparrmana miała miejsce w latach 1765-1767.

59 Forster, Podróż naokoło świata, 44.

60 Paul, „Georg Forster: Empfindsame Weltumseglung”.

61 Davies, Na krańce świata, 541.

62 William Wales (1734-1798) brytyjski matematyk i astronom.

63 Forster, Podróż naokoło świata, 62.

64 Ibidem.

65 Kornacki, „Jerzy Adam Forster - naukowiec rodem z Żuław”, 136-137.

${ }_{66}$ Forster, Podróż naokoło świata, 78. Zatoka Dusky Bay. 
i cztery dni' ${ }^{67}$ cieszyła się świeżym jedzeniem i słodką wodą. W sierpniu $1773 \mathrm{r}$. żeglarze przybyli na Tahiti, gdzie przyjął ich miejscowy król 0-Aheatua ${ }^{68}$. Patrząc życzliwie na krajowców, Georg z troską myślał o ich przyszłości: „Ubolewać wypada, że wszystkie nasze odkrywcze wyprawy zawsze kosztowały życie pewnej ilości niewinnych ludzi, ale te ciężkie straty zadawane drobnym, niecywilizowanym społecznościom, które odwiedzali Europejczycy, są drobnostką w porównaniu z niepowetowanymi szkodami, jakie wyrządzono dzikim, deprawując ich moralnie [...], najmniej ucierpieli ci z nich, którzy zawsze trzymali się z dala od nas"69.

W marcu $1774 \mathrm{r}$. odwiedzono Wyspę Wielkanocną ${ }^{70}$ i ponownie Tahiti ${ }^{71}$. W maju „Resolution” dotarła do Wysp Towarzyskich, w czerwcu do Wysp Przyjacielskich, następnie odkryto Nowe Hebrydy i wyspę Malikolo ${ }^{72}$ oraz Nową Kaledonię i wyspę Norfolk ${ }^{73}$. W Nowej Kaledonii, skuszeni perspektywą zjedzenia świeżej ryby, obaj Forsterowie wraz z kapitanem Cookiem zatruli się wątrobą tetradona. Gdyby nie szybka pomoc medyczna - środki wymiotne i napotne - mogliby przypłacić ten obiad życiem ${ }^{74}$. Odpoczynek latem 1774 r., trzeci na Nowej Zelandii, pozwolił załogom przygotować się do uciążliwej podróży powrotnej. Nabierano sił, uzupełniano zapasy pożywienia i wody pitnej. Trudy podróży wszystkim dawały się już we znaki. Johann Reinhold, cierpiący na przewlekły reumatyzm, chodził z najwyższym trudem, George’owi dokuczały dolegliwości dróg żółciowych. Usprawiedliwiając się z własnych niedomagań napisał: „Oficerowie statku, którzy odbyli już szereg podróży dokoła globu i doświadczyli wielu trudów, stwierdzali jednogłośnie, że wszystkie przeżyte dawniej cierpienia nie zasługują na porównanie z udrękami obecnej wyprawy"75. Zauważyć przy tym jednak trzeba, że dzięki przezorności Cooka udało się uchronić załogę przed groźnym szkorbutem. Kapitan, przekonany o zbawiennym działaniu kiszonej kapusty, załadował jej w Anglii na statek aż 60 wielkich beczek. Serwowana na posiłki dwa razy w tygodniu aż do wyczerpania zapasów, zaiste zdziałała cuda $^{76}$.

Trasa rejsu powrotnego biegła ku Przylądkowi Dobrej Nadziei, w dalszej drodze załoga zatrzymała się na pięć tygodni w Capetown, a następnie, na krótko, na Wyspie Świętej Heleny, Wniebowstąpienia i Azorach ${ }^{77}$. W marcu 1775 r.

67 Ibidem, 106-107.

68 Ibidem, 115-144.

69 Ibidem, 113-114. G. Forster był idealistą, w jednym ze szkiców napisał: „Są dwie drogi, jakimi można oddziaływać na człowieka, poprzez głowę i serce”. Forster, „Über Proselytenmacherei” 200.

70 Forster, Podróż naokoło świata, 175-201.

71 IV 1774. Ibidem, 202.

72 Ibidem, 228 i nn.

73 Ibidem, 256 i nn.

74 Ibidem, 273-279.

75 Ibidem, 300.

76 Paul, „Georg Forster: Empfindsame Weltumseglung”.

77 Forster, Podróż naokoło świata, 307. 
zamknął się krąg podróży dookoła świata, a 29 lipca 1775 r., przed południem, rzucono cumy w porcie Spithead w Angliii ${ }^{78}$.

\section{Znów w Anglii}

Wyprawa trwała trzy lata i szesnaście dni. Łączna długość trasy rejsu okrętu „Resolution” ponad trzykrotnie przekroczyła obwód kuli ziemskiej ${ }^{79}$. Nie zrealizowano celu, jakim było odkrycie nowego kontynentu, ustalając jedynie, że nieznany ląd, jeżeli w ogóle istnieje, położony jest poza kołem polarnym ${ }^{80}$. Dzięki chronometrowi, skonstruowanemu przez zegarmistrza Johna Harrisona ${ }^{81}$, ustalono po raz pierwszy poprawne współrzędne wielu wysp Oceanii. Sam Georg Forster obmyślił teorię, wedle której góry lodowe - „wielkie masy lodu, wolnego od cząsteczek soli i posiadającego wszelkie zbawienne i przydatne właściwości czystej wody" 82 - tworzą się samoistnie na oceanie. Przyszłość miała zweryfikować te przypuszczenia.

Podczas wyprawy Forsterowie prowadzili dziennik obserwacji przyrodniczych i geograficznych, zebrali kolekcje fauny, flory, minerałów i okazów kultury materialnej mieszkańców odwiedzanych lądów. W 1776 r. ukazała się w Londynie ich wspólna praca o florze Polinezji: Johannes Reinholdus Forster i Georgius Forster, Characteris Generum Plantarum quas in Insulis Maris Australis. Zawierała ona opis 265 nowych dla nauki gatunków roślin.

Naukowcy zyskali sławę, lecz nie pieniądze, postanowili więc wydać swój dziennik, licząc na zysk - książki podróżnicze cieszyły się dużą popularnością. Było to jednak niemożliwe ze względu na zawarte w kontrakcie przyrzeczenie Johanna Reinholda ${ }^{83}$, który zobowiązał się nie upowszechniać informacji, które mogłyby zagrozić interesom Imperium, a do takich można było zaliczyć wskazówki dotyczące lokalizacji poszczególnych wysp i lądów. Aby obejść krępujące zakazy, opracowaniem wspomnień zajął się niezwiązany umową Georg. Przygotował relację: A voyage round the World in HMS "Resolution" commanded by Captain Cook, during the years $1772-1775^{84}$, która ukazała się w Londynie w 1777 r., półtora miesiąca przed wydaniem oficjalnych dzienników kapitana Jamesa Cooka. Jej wydaniu towarzyszyła atmosfera skandalu, co z pewnością przyczyniło się do wzrostu

$78 \quad$ Ibidem, 327.

79 Ibidem.

$80 \quad$ Ibidem, 328.

81 John Harrison (1693-1776), brytyjski zegarmistrz, konstruktor pierwszego chronometru.

82 Ibidem.

83 Johann Reinhold wydał w Londynie w 1778. Observations made during a voyage round the world. Andrzej Piskozub, Leksykon morskich odkryć geograficznych (Gdańsk: Marpress, 1996), 70.

${ }^{84}$ Podróż naokoło świata na jednomasztowcu Jego Brytyjskiej Królewskiej Mości „Resolution”, dowodzonym przez kapitana Jamesa Cooka w latach 1772-1775. 
sprzedaży - w ciągu kilku miesięcy książka stała się bestsellerem w Europie ${ }^{85}$, została również znakomicie przyjęta przez środowiska naukowe. Georg Forster, będący bystrym obserwatorem, opisywał wszystko, co wydało mu się ciekawe, malując barwny obraz życia ludzi na odległych lądach w momencie zetknięcia $\mathrm{z}$ białym człowiekiem.

Publikacja przyniosła mu uznanie i jako dwudziestotrzylatek został powołany na członka Akademii w Neapolu, Towarzystwa Królewskiego w Londynie, Akademii Nauk w Madrycie i Berlinie oraz paru innych, mniej znaczących towarzystw naukowych. Honory objęły w takim samym stopniu Johanna Reinholda. Gdańskie Towarzystwo Naukowe w 1776 r. zaliczyło go do grona swoich członków „Zamiejscowych" ${ }^{86}$. Londyński dom Forsterów stał się miejscem pielgrzymek ludzi nauki i arystokratów. Mimo to rodzina tonęła w zobowiązaniach, a Johann Reinhold za długi trafił do więzienia. Georg starał się jak mógł ratować ojca z opresji i ostatecznie 2 października 1777 r. opuścił Anglię, udając się do Niemiec, gdzie spodziewał się znaleźć bogatych i wpływowych protektorów.

Najpierw pojawił się w Paryżu, a w 1778 r. zaś w Hamburgu i Hadze ${ }^{87}$. Ostatecznie zatrudnienie znalazł w Kassel. Tamtejszy książę Fryderyk II ${ }^{88}$ (1760-1785), założyciel słynnej Akademii, zwanej Collegium Carolinum, pozyskiwał naukowców z całej Europy. Dwudziestopięcioletni Georg, który w całym swoim życiu do szkoły uczęszczał przez niecałe dwa lata i nigdy w zasadzie nie studiował, otrzymał posadę profesora historii naturalnej z roczną pensją 450 talarów ${ }^{89}$. Dzięki staraniom przyjaciół książę uregulował również długi Johanna Reinholda, pomagając mu opuścić mury więzienia.

W Collegium Georg uczył pięć lat, od 1779 r. ${ }^{90}$, a oprócz wykładów zajmował się pisaniem i tłumaczeniem. Skromną profesorską pensją dzielił się z resztą rodziny, regularnie wysyłał do nich listy i za pośrednictwem kolegów z loży masońskiej ${ }^{91}$ starał się znaleźć posadę dla ojca. Johannowi Reinholdowi zaproponowano wkrótce objęcie posady profesora historii naturalnej na Uniwersytecie w Halle ${ }^{92}$. Piastował ją od 1780 r., zdobywając sobie autorytet wśród kolegów i studentów.

85 Niemieckie wydanie w latach 1778-1780. Steiner, „Forster Georg”, 301.

86 Waldemar Borzestowski, „Płynęli z Cookiem”, 30 dni 50 (2003): 54.

87 Bramley, „Georg Forster w Szkole Głównej Wielkiego Księstwa Litewskiego”, 22.

88 Friedrich II von Hessen-Kassel (1720-1785), landgraf Hesji-Kassel od 1760. Wsławił się „sprzedażą" 17 tysięcy swoich żołnierzy do Anglii. Ibidem.

89 Został profesorem mając dwadzieścia pięć lat. Fedorowicz, „Ewolucjonizm na Uniwersytecie Wileńskim przed Darwinem", 15.

90 Steiner, „Forster Georg”, 301. Fedorowicz podaje - od 1778 do 1784. Fedorowicz, „Katedra Historii Naturalnej w dawnej Wszechnicy Wileńskiej”, 89.

91 W Kassel Georg zbliżył się do kół masońskich i wstąpił do zgromadzenia Różokrzyżowców pod imieniem Amandus. Fedorowicz, „Ewolucjonizm na Uniwersytecie Wileńskim przed Darwinem", 15 .

${ }_{92}$ Miasto i miejscowy uniwersytet opisał Staszic: „Akademia w tym mieście bardzo liczna, bo do dwóch tysięcy studentów wynosząca, ufundowana przez Fryderyka I w roku 1694 i od niego nazwana Akademia Fridericiana. Miasto prócz studentów liczy 14000 mieszkańców, zaludnione 
Johann Reinhold przez lata ceniony był jako wybitny znawca języków starożytnych, a przy okazji naturalista. Wykłady, w których odwoływał się do doświadczeń podróżniczych, cieszyły się dużą popularnością. Przygotowując plany zajęć, uwzględniał w ich tematyce nowinki naukowe, razem z George'em Christophem Lichtenbergiem ${ }^{93}$ wydawał czasopismo „Göttingisches Magazin der Wissenschaften und Literatur" ${ }^{\prime 4}$. Jako wykładowca systematycznie rozszerzał zakres tematyczny swoich badań i prowadzonych zajęć, w następnych latach prowadził wykłady $\mathrm{z}$ mineralogii, rolnictwa, a nawet technologii, sporo publikując w niemieckich czasopismach naukowych ${ }^{95}$. Powierzono mu również opiekę nad uniwersyteckim ogrodem botanicznym ${ }^{96}$.

\section{Szkoła Główna w Wilnie}

W 1783 r. przewodniczący Komisji Edukacji Narodowej, prymas Michał Poniatowski, brat króla Stanisława Augusta, zwrócił się do Georga, którego kontrakt w Kassel właśnie się kończył, z propozycją objęcia katedry historii naturalnej w Szkole Głównej Wielkiego Księstwa Litewskiego w Wilnie.

Początkowo zwrócono się z propozycją do Johanna Reinholda, który wysłał do Polski długą listę życzeń, żądając wysokiego wynagrodzenia, w tym dodatkowej, rocznej pensji wypłaconej z góry, solidnego mieszkania z opałem, zwolnienia z opłat celnych i pocztowych, urządzenia ogrodu botanicznego, zoologicznego i mineralogicznego, przekazania na własne potrzeby wiejskiego gospodarstwa, polskiego tytułu szlacheckiego, a także katedry dla syna. Były to warunki nie do przyjęcia ${ }^{97}$. W ostatnim akapicie listu Johann sugerował, że być może posadą w Wilnie byłby zainteresowany jego syn Georg. Prymas Michał Poniatowski, w piśmie do jednego z członków Towarzystwa do Ksiąg Elementarnych uznawał, że Georg Forster, urodzony jako poddany króla polskiego, być może zechce z tego powodu powrócić do Ojczyzny i „wspólnie pracować dla jej dobra”.

Młodszy z Forsterów przyjął propozycję. Warunki finansowe, jakie zaoferowano George’owi były wyjątkowo korzystne: otrzymał 200 dukatów na koszty podróży, darmowe mieszkanie oraz uposażenie - 400 dukatów rocznie. Komisja zgodziła się również uregulować jego długi, a było ich niemało - 530 dukatów ${ }^{98}$. Umowa

przez kalwinów, hugenotów francuskich i wygnańców z Palatynatu”. Dziennik podróży ks. Stanisława Staszica (1777-1791), red. A. Kraushar, t. 1 (Warszawa: 1903), 62-63.

93 Georg Christoph Lichtenberg (1742-1799), niemiecki profesor fizyki.

94 W latach 1780-1785. Bramley, Johann Reinhold Forster i Johann George Adam Forster, 255.

95 Głównie „Göttingen Magazine”.

96 Ibidem, 264.

${ }_{97}$ List z 3 XI 1783. Sauerland, „Georg Forster w Wilnie”, 172-173.

98 Dwa razy tyle, co w Kassel. Fedorowicz, „Ewolucjonizm na Uniwersytecie Wileńskim przed Darwinem", 16. 
została zawarta na dziewięć lat ${ }^{99}$. Uradowany Georg wyruszył w drogę, a w każdym z mijanych miejsc - Getyndze, Weimarze, Halle, Lipsku, Dreźnie, Pradze, Wiedniu, Krakowie, Warszawie i Grodnie - był entuzjastycznie przyjmowany ${ }^{100}$.

W kwietniu 1784 r. przebywał w Getyndze, w domu swego przyszłego teścia, znanego niemieckiego filologa Christiana Gottloba Heyne'ego. Następnie przez Weimar, gdzie spotkał się z Johannem Wolfgangiem Goethem, następnie przez Halle, Lipsk, Drezno i Pragę dotarł w sierpniu 1784 r. do Wiednia. Audiencji udzielił mu sam cesarz Józef II, który z dezaprobatą odniósł się do planów wiązania naukowej przyszłości z Wilnem. W Krakowie Georg Forster był we wrześniu tego samego roku; czekała tam na niego delegacja polskich uczonych i dyplomatów. W ich towarzystwie zwiedził kopalnię soli w Wieliczce ${ }^{101}$. Jednak kraj, który oglądał z okien karety, nie przypadł mu do serca - był „biedny, brudny, po prostu brzydki”"102. Swoje przeżycia opisuje tak: „I choć byłem na wszystko nastawiony, przeraziłem się okropnie wjeżdżając do tego kraju, jego rozkład, brud w sensie zarówno moralnym jak i fizycznym, półdzikość i niska kultura jego narodu, widok piaszczystej ziemi, pokrytej wszędzie czarnymi lasami, przerosły wszelkie moje oczekiwania"103. Także język polski nie wzbudzał jego zachwytu, wydawał mu się ciężki i barbarzyński, z nadmierną ilością spółgłosek. Swoje spostrzeżenia z pobytu w Rzeczpospolitej Georg notował w dzienniku, który wiele lat później został wydany w Niemczech ${ }^{104}$. Dnia 7 października 1784 r. Georg przybył do Warszawy, a 2 listopada dotarł do Grodna. Tam został przedstawiony królowi Polski, Stanisławowi Augustowi ${ }^{105}$.

Do Wilna nowy profesor historii naturalnej przybył 18 listopada $1784 \mathrm{r}^{106}$ Na początku posługiwał się $\mathrm{w}$ kontaktach $\mathrm{z}$ gronem pedagogicznym i studentami łaciną, lecz coraz częściej starał się jednak mówić po polsku. Jego wykłady cieszyły się popularnością, były prowadzone w sposób nowatorski, obejmowały botanikę, zoologię i mineralogię. Forster miał zwyczaj objaśniania wszystkiego

\section{Ibidem.}

100 Sauerland, „Georg Forster w Wilnie”, 166.

101 Bramley, „Georg Forster w Szkole Głównej Wielkiego Księstwa Litewskiego”, 32.

102 Więcej na ten temat Sauerland, „Georg Forster w Wilnie”, 166-167.

103 „So gefasst ich auf alles war, erschrak ich doch heftig bei meinem Eintritt in dieses Land, es war der Verfall, die Unfläterei im moralischen und physischen Verstande, die Halbwildheit und Halbkultur des Volks, die Ansicht des sandigen, mit schwarzen Wäldern überall bedeckten Landes, die über alle Vorstellungen gingen, die ich mir hatte machen können”. Forster, Werke, 320.

104 W Niemczech w serii „Deutsche Literaturdenkmale des 18 und 19 Jahrhunderts”, H. 149, Berlin 1914. W Polsce: Jan Jerzy Forster, „Dziennik podróży po Polsce”, przełożył z języka niemieckiego, wstępem i przypisami opatrzył Zawadzki. Archiwum Historii Medycyny 1-2 (1958); 135-159, 3-4 (1958); 293-319.

105 Fedorowicz, „Ewolucjonizm na Uniwersytecie Wileńskim przed Darwinem”, 16. O Stanisławie Auguście Poniatowskim powiedział, że jest „wielkim przyjacielem Anglii i wszystkiego, co angielskie". Stanowiło to nie lada komplement w ustach Georga Forstera, duchowo i nie tylko odczuwającego związki z krajem przodków. Sauerland, „Georg Forster w Wilnie”, 170.

106 Forster, „Podróż po Polsce”, 41-103. 
na podstawie przykładów, często prezentował materiały przyrodnicze i etnograficzne przywiezione z odległych miejsc ${ }^{107}$. Był przekonany, że nie należy obarczać studentów wiedzą zbyteczną, bo: „Skoro liczba tych rzeczy w przyrodzie, które przynoszą pożytek ludziom, zamyka się w niewielkim wymiarze, to czyż wolno obciążać pamięć uczniów rozmaitością innych niepotrzebnych rzeczy i czy słusznie przyrodnicy życie całe trawią na ich badaniu? Czy nie byłoby rzeczą rozsądniejszą poprzestawać na poznawaniu wyłącznie rzeczy pożytecznych?”108.

Dnia 27 grudnia 1784 r. napisał do ojca: „Teraz mam wystarczająco dużo pracy, ponieważ chcę uporządkować moją własną kolekcję naturaliów, co odbywa się powoli z powodu braku dobrych pracowników i niemożności szybkiego wykonania szaf. Bardzo martwię się, gdyż minerały, książki i pamiątki z Tahiti, które mi wysłaliście, jeszcze do mnie nie dotarły. Nie rozpocząłem jeszcze swoich zajęć lekcyjnych i nie zrobię tego, zanim kolekcja nie zostanie uporządkowana"109. Zakupił również w Dreźnie zbiór minerałów, który zasilił zasoby miejscowego gabinetu historii naturalnej i był przez niego wykorzystywany jako pomoc naukowa. Wspomina o tym w swoim dzienniku Maria Ludwika Byszewska - szambelanowa Stanisława Augusta Poniatowskiego: „Bardzo mi się spodobał JP Forster, że się krótko i jasno eksplikował, pokazując różne kamienie i kruszce"110.

Dnia 2 lutego 1785 r. w Szkole Głównej Wielkiego Księstwa Litewskiego w Wilnie Georg wygłosił mowę Limites Historiae naturalis ${ }^{11}$. Oświadczył wówczas: „Jeżeli miałbym wyrazić nieco gruntowniej przemyślany sąd o słusznych pragnieniach wartościowego człowieka, to muszę oświadczyć, zgodnie z opinią powszechną, że to stanowisko, którym obdarowała mnie najwyższa życzliwość znakomitych rządców spraw oświecenia publicznego, jest zarazem najbardziej godnym celem moich pragnień i bardzo cennym zaszczytem"112. Tam też powiedział więcej o celach współczesnej nauki: „Nasza nauka wyraźnie rozpada się na dwie główne części, z których pierwsza wiedzie do osiągnięcia poznania rzeczy, a druga ma na celu pożytek”. Przestrzegał: „Gdy zaś jest to cechą zwłaszcza pospolitych i zwierzęcych nieomal usposobień, że korzyści stawiają ponad szlachetność i lekceważą wszystko, z czego nie widzą możliwości wydobycia dla siebie

107 Tam trzyletni program wykładów na uczelni wileńskiej. Fedorowicz, „Katedra Historii Naturalnej w dawnej Wszechnicy Wileńskiej”, 93-96.

108 „Mowa Jerzego Forstera pt. Limites Historiae naturalis wygłoszona 2 lutego 1785 r. w Szkole Głównej Wielkiego Księstwa Litewskiego w Wilnie", 9.

109 „Wybrana korespondencja rodziny Forsterów”, w Ziółkowska, Olczak, Z Forsterami i Cookiem, 101.

110 „Dziennik podróży do Wilna odbytej w 1786 r. przez Szambelanową Byszewską”, w Kronika Rodzinna. Pismo dwutygodniowe poświęcone literaturze, sprawom domowym i społecznym, red. Aleksandra Borkowska (Warszawa: 1873), 622.

111 Wydana w Lipsku w roku 1843. Polskie wydanie: „Mowa Jerzego Forstera pt. Limites Historiae naturalis wygłoszona 2 lutego 1785 r. w Szkole Głównej Wielkiego Księstwa Litewskiego w Wilnie".

112 „Mowa Jerzego Forstera pt. Limites Historiae naturalis wygłoszona 2 lutego 1785 r. w Szkole Głównej Wielkiego Księstwa Litewskiego w Wilnie”, 13. 
pożytku i owoców, tak znów z drugiej strony u ludzi gruntownie wykształconych, którzy godność cenią ponad wszystko i troszczą się o wspólne dobro ludzi oraz o jego wzbogacenie, nierzadko zdarza się, że zbaczają w innym kierunku i nazbyt dumnie traktując przewagę człowieka, bredzą coś o tym, jakoby cały świat z nieskończoną rozmaitością rzeczy dla niego został stworzony. Tej pychy zaś żaden argument tak skutecznie nie złamie, jak idące w głąb badanie przyrody ${ }^{113}$ ", wskazując jednocześnie właściwą drogę rozwoju: „[... [ rodzaj ludzki stale liczebnie przyrasta. Dlatego też, aby zaspokoić potrzeby wszystkich, musimy wynajdywać dla nas w królestwie przyrody wciąż nowe środki utrzymania, musimy uczyć się, jak zaspokajać głód i pragnienie oraz stosować przeciw chorobom, nieznanym przodkom naszym, leki, o których nie słyszano dawniej; wykorzystywać na tysiączne sposoby bogactwa natury, by podnosić wygodę i kulturę w sposobie życia; idąc za wzorem natury łączyć $w$ wytworach rzemiosła pożyteczność $z$ powabem formy i rozbudzać w duszach wszystkich ludzi jakieś subtelniejsze poczucie piękna i harmonii, które łagodzi obyczaje i odgradza je od dzikości, by cieszyli się i czerpali ustawicznie radość z owej składności i wdzięku, które zawierają się w kształtach, barwach, tonach, melodiach, w ruchach, a wreszcie w słowach"114.

W Limites Historiae naturalis wyłożył klarownie swój pogląd na badania naukowe: „Prawdziwy obserwator powinien przyjąć jako zasadę: iść za przewodem natury i doświadczenia, nie dawać zbytnio wiary cudzemu autorytetowi, niczym pochopnie się nie zachwycać, lecz przyglądać się wszystkiemu ze spokojem mędrca"115.

$\mathrm{Na}$ wykłady Forstera uczęszczało kilkunastu słuchaczy ${ }^{116}$, wiosną 1787 r. zorganizował prywatny kurs botaniki i zoologii dla studentów, wśród nich znajdował się Stanisław Jundziłł ${ }^{117}$, późniejszy profesor botaniki na Uniwersytecie Wileńskim. Georg Forster prowadził również seminaria z paleontologii i anatomii porównawczej. Stworzył autorski program zajęć, wykłady opierał na własnych rękopisach, przygotowywanych do druku pracach. Jego nowatorskie metody rewidowały obowiązujące dotąd zasady szkolnictwa wyższego w Polsce. Zyskiwało mu to popularność wśród studentów, ale też wywoływało niechęć części środowiska naukowego ${ }^{118}$. Stanisław Jundziłł tak ocenił jego pobyt: „Przy rozległych swych i gruntownych, a dokładnych naukach i wiadomościach, przy łatwym, zwięzłym i płynnym w różnych językach tłumaczeniu się, przy szczerej o postęp uczniów gorliwości, nie mógł dla krótkiego w Akademii pobytu zamierzonych przez

$113 \quad$ Ibidem, 31.

114 „Mowa Jerzego Forstera pt. Limites Historiae naturalis wygłoszona 2 lutego 1785 r. w Szkole Głównej Wielkiego Księstwa Litewskiego w Wilnie”, 35.

115 Ibidem, 25.

116 Bramley, „Georg Forster w Szkole Głównej Wielkiego Księstwa Litewskiego” 20.

117 Stanisław Bonifacy Jundził (1761-1847), pijar, wychowanek Szkoły Głównej. Janina Kamińska, „Akademia wileńska w latach 1792-1799”, Rozprawy z dziejów oświaty 40 (2000): 9.

118 Ziółkowski, Olczak, Z Forsterem i Cookiem na kraniec świata, 60. 
Komisję przynieść korzyści” ${ }^{119}$. Podczas bytności w Wilnie zainicjował powiększenie istniejącego ogrodu botanicznego i przeniesienie go w inne, korzystniejsze w jego przekonaniu miejsce, za budynkiem Kolegium Medycznego. Nie zrezygnował również z wycieczek przyrodniczych po okolicy, gromadził okazy flory i przymierzał się do napisania działa dotyczącego flory i fauny Litwy ${ }^{120}$.

Forster starał się, przynajmniej na początku, wejść w miejscowe środowisko naukowe, nawiązał przyjazne relacje z rektorem Szkoły, astronomem Marcinem Poczobuttem ${ }^{121}$. Nie przez wszystkich jednak był lubiany. Bardzo krytycznie wypowiadał się na jego temat Jędrzej Śniadeckii ${ }^{122}$, mimo że nigdy nie spotkali się osobiście, a całą wiedzę o Forsterze czerpał od osób trzecich. Napisał o nim: „[...] sprowadzony tu był na Historię Naturalną, której nie umiał; zamiast dawać lekcje pisał i tłumaczył książki, o które wprzódy już był kontrakta z księgarzami niemieckimi porobił; na koniec wszedłszy w inną umowę z Imperatorową Katarzyną, wyjechał gadając i pisząc paszkwile na Polaków"123.

Kiedy po roku spędzonym na Litwie przyjechał na krótko do Niemiec, ożenił się z Therese $\mathrm{z}$ domu Heyne ${ }^{124}$ i odebrał przyznany mu doktorat medycyny Uniwersytetu w Halle ${ }^{125}$. Po powrocie do Wilna na świat przyszła jego pierworodna córka, Therese ${ }^{126}$.

W zamierzeniu Komisji Edukacji Narodowej wprowadzenie George’a do kadry miejscowego Uniwersytetu, w którym silną grupę stanowili w dalszym ciągu eksjezuici, miało stanowić jeden z elementów reformy przestarzałych form nauczania $^{127}$. Tymczasem on doświadczał zmiennych nastrojów, w Dzienniku podróży po Polsce napisał: „Dusza moja smuci się i nie może zapomnieć Wiednia, a nawet Kassel"128. George'a raziła prowincjonalność tutejszych elit, o czym pisał do swego ojca: „Chociaż łatwo jest w tak mało oświeconym kraju, jakim jest Polska, za kogoś uchodzić, jednak ja naprawdę chcę się przydać i nie stwarzać pozorów” ${ }^{129}$. Oburzało go również złe położenie ludu miejscowego, napisał, że: „znajduje się on

119 Stanisław Jundził, „Jan i Jerzy Forsterowie”, Tygodnik Ilustrowany 290-291 (1865): 25.

120 Bramley, Johann Reinhold Forster i Johann George Adam Forster, 260.

121 Marcin Poczobutt (1728-1810) rektor Szkoły Głównej od 1780. Kamińska, „Akademia wileńska w latach 1792-1799”, 4.

122 Jędrzej Śniadecki (1768-1784), biolog i lekarz. Fedorowicz, „Katedra Historii Naturalnej w dawnej Wszechnicy Wileńskiej”, 91.

123 Fedorowicz, „Ewolucjonizm na Uniwersytecie Wileńskim przed Darwinem”, 17.

124 Therese Huber, $z$ domu Heyne (1764-1829). Pisarka i dziennikarka. Po śmierci męża poślubiła wydawcę Ludwika Ferdinanda Hubera.

12522 VI 1785. Fedorowicz, „Wstęp”, w Mowa Jerzego Forstera pt. Limites Historiae naturalis wygłoszona 2 lutego 1785 r. w Szkole Głównej Wielkiego Księstwa Litewskiego w Wilnie, 9.

126 Córka Georga Forstera - Therese (1786-1862), była wydawczynią dzieł zebranych ojca.

127 O reorganizacji w szkole po 1795. Kamińska, „Akademia wileńska w latach 1792-1799”, 5-6. Domoradzki, Pawlikowska-Brożek, „Uniwersytet Wileński”, 127.

${ }_{128}$ Ziółkowski, Olczak, Z Forsterem i Cookiem na kraniec świata, 64.

129 List z Wilna, 22 listopada 1784 r. „Wybrana korespondencja rodziny Forsterów”, 98. 
w położeniu bydła pociągowego, pozbawiony jest wszelkich praw ludzkich i nie jest traktowany jako część narodu polskiego, mimo iż stanowi jego większość"130. Również warunki, które zapewniła mu uczelnia, znacząco odbiegały od obiecanych, co spostrzegła także wspomniana już szambelanowa Byszewska: „Widziałam stancję J.P. Forstera, w której mieszkał i miał obowiązek dawania lekcyi swoich; ta była szczupła i nie dłuższa nad łokci 8 , a szerokości łokci 4. Żałowałam, że ten godny człowiek tak mało ma miejsca" ${ }^{131}$. Być może jednak, mimo tych zastrzeżeń, Georg pozostałby w Wilnie do końca kontraktu, gdyby nie kolejna kusząca propozycja z cesarskiego dworu ${ }^{132}$.

Katarzyna II, dowiedziawszy się o pobycie Forstera w Wilnie od swego posła Otto Magnusa von Stackelberga, postanowiła zorganizować wielką wyprawę morską wokół Ziemi. Do udziału w niej zapraszała George’a. Oficjalną propozycję, w czerwcu 1787 r., przekazał Forsterowi osobiście kontradmirał G.I. Mułowski, który specjalnie w tym celu przybył do Wilna ${ }^{133}$. Rząd rosyjski zobowiązał się pokryć wszelkie koszty i zobowiązania, wynikłe z tytułu zerwania kontraktu z uczelnią w Wilnie ${ }^{134}$. Propozycja wyglądała na bardzo poważną, więc Georg zdecydował się opuścić uczelnię ${ }^{135}$. W lipcu 1787 r. wręczył swoją rezygnację, a pod koniec sierpnia pełen entuzjazmu Forster wyjechał z Wilna do Getyngi ${ }^{136}$, aby tam przygotować się do wyprawy. Sama Akademia Wileńska ${ }^{137}$ chlubiła się jeszcze po latach obecnością Forstera na uczelni. W jednym z listów ks. Adam Kazimierz Czartoryski, zabiegając u swego syna, ks. Adama Jerzego Czartoryskiego - od 1802 r. kuratora okręgu wileńskiego i bliskiego współpracownika cara Aleksandra - o pomoc dla uczelni, wymienił go wśród najwybitniejszych profesorów ${ }^{138}$.

Wybuch wojny rosyjsko-tureckiej, a potem rosyjsko-szwedzkiej sprawił, że wyprawa nie doszła do skutku. Rozczarowany Forster stał się człowiekiem bez pracy i perspektyw, z kurczącymi się w zastraszającym tempie oszczędnościami.

130 Fedorowicz, „Ewolucjonizm na Uniwersytecie Wileńskim przed Darwinem”, 17.

131 „Dziennik podróży do Wilna odbytej w 1786 r. przez Szambelanową Byszewską”, 621.

132 Więcej o okolicznościach odejścia Forstera z Wilna i rosyjskiej propozycji w opinii ks. St. Jundziłła, cytowanego: Fedorowicz, „Katedra Historii Naturalnej w dawnej Wszechnicy Wileńskiej”, 89.

133 Wyprawie patronowała caryca i admirał Aleksiej N. Sieniawin. Fedorowicz, „Ewolucjonizm na Uniwersytecie Wileńskim przed Darwinem”, 18.

134 Steiner, „Forster Georg”, 301.

135 Celem czteroletniej wyprawy w składzie 36 okrętów miało być m.in. zbadanie wybrzeży rosyjskich od Ochocka i Ameryki. Po jej zakończeniu Georg miał zyskać profesurę w Petersburgu. Kornacki, „Jerzy Adam Forster - naukowiec rodem z Żuław”,158-159.

136 Po wyjeździe Forstera jego katedra pozostała pusta przez pięć lat. Dopiero w 1792 r. objął ją Ferdynand Spitznagel z Wiednia. Fedorowicz, „Organizacja studiów przyrodniczych na Wszechnicy Wileńskiej”, 35.

137 Szkoła Główna działała w latach od 1781 do 1795 . Uniwersytet powołano w 1803.

138 „Między swoimi profesorami miała ona rektora Poczobutta, astronoma znanego w całej Europie, jego adiunkta Strzeckiego, który właśnie zmarł, Tomaszewskiego, profesora fizyki doświadczalnej, Forstera, Sartorisa, Giliberta” za Domoradzki, Pawlikowska-Brożek, „Uniwersytet Wileński”, 127. 
Ostatecznie z kilku propozycji wybrał w 1788 r. posadę bibliotekarza w Moguncji nad Renem ${ }^{139}$.

W 1790 r. Georg udał się w podróż, wcale nie odległą, która zapewniła mu trwałe miejsce w historii kultury niemieckiej, jej owocem było arcydzieło literatury podróżniczej: Ansichten vom Niederrhein, von Brabant, Flandern, Holland, England und Frenkreich im April, Mai und Juni 1790 ${ }^{140}$. W wędrówce przez Kolonię, Düsseldorf, Akwizgran, Belgię, Holandię do Anglii towarzyszył mu młody arystokrata, Aleksander von Humboldt, przyszły słynny geograf i podróżnik. Forster wywarł duży wpływ na przekonania Humboldta, rozbudził zainteresowania podróżami, traktowanymi jako doświadczenie naukowe, przekonał do badań porównawczych.

\section{Niemiecki jakobin}

Pod koniec XVIII w. cała Europa przyglądała się z uwagą i napięciem temu, co działo się nad Sekwaną. W Niemczech, rozbitych na dziesiątki królestw i księstw, zapanowała moda na rewolucyjność. Joanna Schopenhauer opisała ją trafnie: „Ale my, oddaleni, myśleliśmy jedynie o występkach ludzi potężnych i wielkich, które obecnie wyprowadziły lud, nie dający się ujarzmić, i usprawiedliwiały go w tym, czego nie mogliśmy pochwalać. Wesoło śpiewaliśmy: Pójdą, pójdą, pójdą! Arystokraci na latarnie! ${ }^{141}$ - ale bylibyśmy na pół martwi, gdybyśmy musieli patrzeć na prowadzonych na śmierć, zwłaszcza ja, która nie mogłam nigdy bez trwożliwego bicia serca wydać wyroku śmierci na moich upierzonych, podwórzowych podwładnych"142.

Kiedy w 1792 r. wojska francuskie wkroczyły do Moguncji, George’owi, który przebywał w mieście, udzielił się rewolucyjny duch ${ }^{143} \mathrm{i}$ wstąpił do klubu jakobinów ${ }^{144}$. W październiku tego samego roku założył wraz z przyjacielem, Andreasem Hofmannem ${ }^{145}$, Towarzystwo Przyjaciół Wolności i Równości ${ }^{146}$. Wybrany deputowanym rewolucyjnego parlamentu Forster był jednym z twórców ustawy, na mocy

139 Steiner, „Forster Georg”, 301. Istniał tam uniwersytet od 1477. Zamknięty w 1798 (tylko wydział medyczny funkcjonował do 1823) został reaktywowany dopiero w 1946.

140 Wydane w trzech tomach w latach 1791-1794. Ibidem.

141 Ah ça ira, ça ira, ça ira! Les aristocrates à la laterne!

142 Joanna Schopenhauer, Gdańskie wspomnienia młodości (Wrocław: Zakład Narodowy im. Ossolińskich, 1959), 245-246.

143 Postawa George'a Forstera wobec rewolucji ewoluowała, w swoim liście do żony z 16 IV 1793 napisał: „Ja miałbym napisać historię tych przerażających czasów? Nie mogę. Och, odkąd wiem, że w rewolucji nie ma żadnej cnoty, brzydzę się nią. Mógłbym z dala od tego idealistycznego marzycielstwa zdążać do celu w towarzystwie ludzi nie idealnych, upadać, wstawać i iść dalej. Ale z tymi diabłami, jakimi wszyscy tu są, jest to grzech wobec ludzkości, wobec świętej matki ziemi”. Forster, „Brief aus Paris an seine Frau”, 480.

144 Steiner, „Forster Georg”, 301.

145 Andreas Joseph Hofmann (1752-1849), niemiecki filozof.

146 „Freunde der Freiheit und Gleichheit”. 
której Nadreńsko-Niemiecki Konwent Narodowy ${ }^{147}$ ogłosił powstanie Republiki Mogunckiej $^{148}$. Georg został jej wiceprezydentem. Jako zwolennik ścisłego powiązania młodego państwa z Francją, podróżował w 1792 r. do Paryża ${ }^{149}$. Kiedy do Johanna Reinholda, pruskiego profesora w mieście Halle, dotarły wiadomości dotyczące działalności George’a, nie krył swego oburzenia i odciął się od syna publicznie ${ }^{150}$.

W lipcu 1793 r. wojska pruskie zdobyły Moguncję, w ten sposób zakończył się kilkumiesięczny żywot młodej republiki. Tam, gdzie wkroczył stary porządek i zasady, nie było miejsca dla rewolucjonistów. Georg wyjechał więc ponownie do Francji. Jego dalsza działalność nie trwała jednak długo, przyjęty z rezerwą przez francuskich jakobinów, z końcem 1793 r. zaczął poważnie chorować na nerki ${ }^{151}$. Georg Forster nigdy nie przestał myśleć o dalekiej wyprawie, przeglądał mapy i uczył się wciąż nowych języków, ostatnim, jaki poznawał, był perski. Przez sześć miesięcy żył w nędzy, pozbawiony jakiejkolwiek opieki. Umarł w Paryżu, 10 stycznia 1794 r., przeżywszy zaledwie trzydzieści dziewięć lat ${ }^{152}$. Jego ojciec zmarł kilka lat później - 9 grudnia 1798 r., w Halle.

Działalność Johanna Reinholda i George’a Adama Forsterów cieszyła się dużym zainteresowaniem w czasach, w których żyli. Nic dziwnego - stanowili wszak uosobienie ideałów oświecenia. Byli ludźmi nauki, podejmującymi się trudów dalekich podróży, by odkrywać nieznane lądy, zwierzęta i rośliny, zjawiska przyrodnicze i nasze ludzkie przypadłości, zrozumieć naturę w całym bogactwie i złożoności. Dzięki opublikowanym książkom, a szczególnie relacji z wielkiej morskiej wyprawy z kapitanem Jamesem Cookiem, stali się rozpoznawalni w salonach, uzyskali posady wykładowców i mogli dzielić się wiedzą z młodymi ludźmi, kształtując nie tylko świat ich wyobrażeń, ale również ich postawy. W wykładach odwoływali się do swych bogatych doświadczeń, korzystali z przywiezionych zbiorów i pozyskiwali nowe, cenili również bezpośredni kontakt z przyrodą, tworząc własne zielniki, opracowując zebrane okazy. Na każdej z uczelni troszczyli się o miejscowy ogród botaniczny, wiedząc, że jest on równie ważny dla nich, jak odpowiedni dobór podręczników. Byli encyklopedystami w takim ujęciu, jak rozumiała to ich epoka, starali się unikać zbytniej specjalizacji, w oparciu o dziedziny pokrewne rozbudowywali dorobek naukowy, w którym prócz wiodącej biologii, pojawiają się prace zoologiczne, mineralogiczne, geologiczne, etnograficzne, a nawet antropologiczne.

147 Otwarty w III 1793.

148 Niekiedy pod nazwą Republika Reńsko-Niemiecka.

149 Steiner, „Forster Georg”, 301.

150 Wyraził się, że syn powinien zawisnąć na szubienicy. tAugustowska, „Jerzy Forster, uczony i podróżnik epoki oświecenia. Karta z dziejów nauki gdańskiej”,163. Odcięli się do niego przyjaciele, napisał w liście z 8 I 1783: „Moja cała korespondencja zakończyła się. Nikt do mnie nie pisze”. „Wybrana korespondencja rodziny Forsterów”, 87.

151 W ostatnim liście do żony, z 4 I 1794, skarżył się na ból brzucha, jelit i bezsenność. Kornacki, „Jerzy Adam Forster - naukowiec rodem z Żuław”, 163.

${ }_{152}$ Mieszkał przy ulicy Rue des Moulins. Ibidem. 
Stanowi to walor i słabość jednocześnie, nie udało im się bowiem w żadnej z dziedzin, którymi się zajmowali, osiągnąć wysokiej pozycji.

Swoje zdolności lingwistyczne Forsterowie wykorzystywali, próbując ustalić powiązania między grupami tubylców z napotkanych wysp. Miało to stworzyć choćby przybliżony zarys ich dawnych migracji. Forsterowie cenili sobie eksperyment i mieli przekonanie, że natura, której człowiek jest ważnym elementem, stanowi rodzaj całości, bardzo cennej i wartej obserwacji, gdyż zawarte w niej prawidła można odnieść do wszystkiego: „Badając prawa i ich stosunki utajone w przyrodzie, dzięki którym rzeczy pozornie przeciwne w istocie swej jednak się kojarzą, natrafiamy na zasadę [...] słuszności i dobra, niezbędną dla szczęśliwego życia, która też o tyle lepiej nam wyjaśni, na czym polega obowiązek, im staranniej poddamy rozpatrzeniu cały chaos zjawisk oraz związek rzeczy małych z wielkimi”"153.

Doświadczenie rewolucji francuskiej położyło cień na dokonania pokolenia z czasów ją poprzedzających. Twórczość Forsterów w części poszła w zapomnienie. Odnajdywana po latach, potrafi jednak w dalszym ciągu zachwycić $\mathrm{i}$ to $\mathrm{w}$ tych partiach, które dotyczą obserwacji, życia codziennego, spotkań, słowem - tego wszystkiego, co opisuje świat, w którym żyli, pozwala go nam odtworzyć i zrozumieć. Nie należy jednak z tego powodu bagatelizować ich ściśle naukowych dokonań, bo choć przeminęła ich odkrywczość, to przecież stanowiły punkt odniesienia dla kolejnych badaczy.

W jednym listów Georg sformułował dość ściśle swój pogląd na edukację w ujęciu filozoficznym i duchowym: „Każdy człowiek na tym świecie, jak się wydaje, musi przejść tę drogę, by stał się tym, kim może się stać i tym sposobem zniknie ból, którego ostatecznego celu nie znamy. On prowadzi wszystkich, którzy go odczuwają, do wyższego stopnia wytrzymałości, do właściwej oceny rzeczy i do rozwoju naszych wszelkich sił duchowych" ${ }^{154}$.

Waldemar Borzestowski

Johann Reinhold and Georg Forster, 18th-century naturalists and travellers

\section{Summary}

Of Scottish descent, Forster family settled in the $18^{\text {th }}$ century in the area near Gdańsk. Johann Reinhold Forster (1729-1798), pastor in Mokry Dwór in Żuławy, a theologian by education, was interested in biology. He instilled his passion in his eldest son, Johann Georg (1754-1794). Together with him, in 1765, he set off for Russia at the invitation of

153 „Mowa Jerzego Forstera pt. Limites Historiae naturalis wygłoszona 2 lutego 1785 r. w Szkole Głównej Wielkiego Księstwa Litewskiego w Wilnie”, 35.

154 List z Lipska, 22 V 1784, „Wybrana korespondencja rodziny Forsterów”, 84. 
tsarina Catherine II. Because the report from the trip of the broad research field did not satisfy the Russian authorities, the Forster were forced to move to England in 1766. There, Johann Reinhold developed his academic career at Warrington University. He resigned from his position in 1767 as the result of the dispute with his colleagues - lecturers.

In 1772, accompanied by his son, he became the member of James Cook's second exploration voyage to the South Seas, including ships "Resolution" and "Adventure". It aimed at reaching the Continent named Terra Australis - the Great Southern Continent. The voyage lasted three years. In 1777, A voyage round the World in HMS "Resolution" commanded by Captain Cook, during the years 1772-1775, the book by Georg Forster was published. It became a world best seller.

In the following years, both Forsters sought university positions in continental Europe. In years 1779-1784, Georg worked at Kassel University, later on in Vilnius (1784-1787), from where he departed to Russia for a short period of time, and next since 1788 he held the position of the librarian in Mainz. Johann Reinhold was associated with the University of Halle (where he died on $9^{\text {th }}$ December 1798). When the French troops entered Mainz in 1792, Georg supported revolutionary changes. He was one of the enthusiasts of the established Republic of Mainz. After the fall of the Republic, he moved to Paris where he died on $10^{\text {th }}$ January 1794 . His father publicly dissociated himself from his son's views.

The article intends to bring closer the figures of both scientists, present their activity in many fields and their complicated life stories. It is done on the basis of fragmented literature, few translations of Georg Forster's works into Polish, and the articles devoted to both Forsters supplemented by selected quotations from German literature. 